\title{
Corruption, the Lack of Academic Integrity and Other Ethical Issues in Higher Education: What Can Be Done Within the Bologna Process?
}

\author{
Elena Denisova-Schmidt
}

\section{Introduction}

Transparency International (TI), an NGO working on corruption worldwide, commonly defines corruption as "the abuse of entrusted power for private gain." In higher education, however, corruption also encompasses "the lack of academic integrity." The second definition applies to both public and private institutions, since what they both offer-education - can be construed as a public good. Corruption might be perceived or it might not; in higher education, however, this differentiation is less relevant (Heyneman 2013). Along with the kinds of monetary and non-monetary corruption that can be found anywhere in society, such as corruption in procurement and favouritism in hiring and/or promoting employees, corruption in higher education can implicate the students themselves, thus exerting an influence over the next generation (Denisova-Schmidt 2016a, b, c, 2017a, b, c, 2018a, b; Denisova-Schmidt and de Wit 2017).

While corruption in higher education is not a new phenomenon, its unprecedented dimensions, the growing challenge of mitigating and preventing it in many academic systems as well as its international aspect are rather new. Can corruption be exported and/or imported with the rise of mobility among students and faculty and the internationalisation of educational institutions? Are universities prepared to deal with actors from endemically corrupt societies? What tools and best practices

\author{
E. Denisova-Schmidt $(\square)$ \\ University of St. Gallen (HSG), St. Gallen, Switzerland \\ e-mail: elena.denisova-schmidt@unisg.ch \\ E. Denisova-Schmidt \\ Boston College, Boston, USA
}

(C) The Author(s) 2018

A. Curaj et al. (eds.), European Higher Education Area: The Impact of Past and Future Policies, https://doi.org/10.1007/978-3-319-77407-7_5 
are particularly effective in increasing academic integrity? Or is it an irreversible process? How can the latest research contribute to the policy debate within the Bologna process?

The paper is structured as follows: first, I discuss the current trends in the general research on corruption and its implications for higher education within the Bologna context, then I give an overview of some successful tools for mitigating academic dishonesty and discuss the challenges of their implementation.

\section{Corruption Research as a Field of Study}

What is "corruption," really? Scholars and practitioners often work with definitions developed by international organisations such as the World Bank, United Nations (UN) and its sub-structures, as well as Transparency International (TI):

"[Corruption is] the abuse of public office for private gain" (World Bank ${ }^{1}$ );

"[Corruption is] the misuse of public power, office or authority for private benefit through bribery, extortion, influence peddling, nepotism, fraud, speed money or embezzlement" $(\mathrm{UNDP})^{2}$;

"Corruption is the abuse of entrusted power for private gain" (Transparency International ${ }^{3}$ ).

In spite of some slight differences in wording, the idea is approximately the same: something that was previously "public" becomes "private", often in an improper way. How does this relate to higher education? While some might argue that these definitions apply to public universities only and do not cover private ones, these definitions, in fact, relate to both public and private institutions since what they both offer - education - is a public good. More concretely: Imagine a student writing a term paper. He or she plagiarizes, which is to say, he or she copies and pastes text from other sources without acknowledging them. The student submits this paper and receives a grade for it. This is fraud - one form of corruption. Taking it a step further, let's say that the faculty member who is responsible for grading this paper chooses to ignore the plagiarism. In this case, the faculty member is misusing an entrusted power for private gain, in the broader sense (Denisova-Schmidt 2017a). Faculty members do not necessarily have to be bribed to do it; their reasons might vary, from being overloaded with other duties to the lack of time to investigate. Some scholars often do not dare to call it "corruption" and mitigate this small "sin" by referring to it as "student dishonesty", "academic dishonesty", "cheating", or just simply "plagiarism” (s. e.g. Curtis et al. 2013; Golunov 2014; Curtis and

\footnotetext{
${ }^{1}$ http://www.worldbank.org/publicsector/anticorrupt/corruptn/cor02.htm\#note1.

${ }^{2}$ https://www.igi-global.com/dictionary/corruption/6010.

${ }^{3}$ https://www.transparency.org/what-is-corruption/.
} 
Vardanega 2016; Chapman and Linder 2016; Denisova-Schmidt 2016a; Denisova-Schmidt et al. 2016a). The challenges of defining "corruption" might also be explained by the fact that corruption is a crime. Some scholars might consider only those activities to be corrupt that have been proven as such by a judge; otherwise, they might refer to the presumption of innocence. Depending on the national context, even an obvious bribe cannot be easily judged to be a bribe, as an advantage caused by this bribe still has to be proven, among other things.

Table 1 Selected examples of corruption in higher education

\begin{tabular}{|c|c|}
\hline $\begin{array}{l}\text { Terms/TI } \\
\text { definitions }^{\text {a }}\end{array}$ & $\begin{array}{l}\text { Bribery } \\
\text { The offering, promising, giving, accepting, or soliciting of an advantage as } \\
\text { an inducement for an action that is illegal, unethical, or a breach of trust. } \\
\text { Inducements can take the form of gifts, loans, fees, rewards, or other } \\
\text { advantages (taxes, services, donations, etc.) }\end{array}$ \\
\hline Examples & $\begin{array}{l}\text { A student bribes a professor to change a grade in his/her favour; a faculty } \\
\text { member bribes a ghostwriter for his/her own publication; university } \\
\text { administration demands bribes from service suppliers }\end{array}$ \\
\hline $\begin{array}{l}\text { Terms/TI } \\
\text { definitions }\end{array}$ & $\begin{array}{l}\text { Collusion } \\
\text { A secret agreement between parties, in the public and/or private sector, to } \\
\text { conspire to commit actions aimed to deceive or commit fraud with the } \\
\text { objective of illicit financial gain. The parties involved often are referred to as } \\
\text { "cartels" }\end{array}$ \\
\hline Examples & $\begin{array}{l}\text { Faculty members ignore or pretend to ignore students' academic } \\
\text { misbehaviour; } \\
\text { Faculty members are involved in "citation" cartels: citing each other's } \\
\text { works/journals without necessity; } \\
\text { Administration chooses the winner in an open tender, based on a prior } \\
\text { agreement }\end{array}$ \\
\hline $\begin{array}{l}\text { Terms/TI } \\
\text { definitions }\end{array}$ & $\begin{array}{l}\text { Conflict of interest } \\
\text { A situation where an individual, or the entity for which this person works, } \\
\text { whether a government, business, media outlet, or civil society organisation, } \\
\text { is confronted with choosing between the duties and demands of their } \\
\text { position and their own private interests }\end{array}$ \\
\hline Examples & $\begin{array}{l}\text { A high-ranking official responsible for accreditation is placed in charge of a } \\
\text { university, for which he and/or she recently worked; } \\
\text { A professor grades his/her nephew/niece or supervises a thesis written by } \\
\text { his/her fiancé; } \\
\text { A university manager responsible for catering buys food from his/her } \\
\text { relatives only }\end{array}$ \\
\hline $\begin{array}{l}\text { Terms/TI } \\
\text { definitions }\end{array}$ & $\begin{array}{l}\text { Favouritism } \\
\text { Patronage: a form of favouritism in which a person is selected, regardless of } \\
\text { qualifications or entitlement, for a job or government benefit because of } \\
\text { political affiliations or connections } \\
\text { Nepotism: a form of favouritism based on acquaintances and familiar } \\
\text { relationships whereby someone in an official position exploits his or her } \\
\text { power and authority to provide a job or favour to a family member or friend, } \\
\text { even though he or she may not be qualified or deserving }\end{array}$ \\
\hline
\end{tabular}


Table 1 (continued)

\begin{tabular}{l|l}
\hline Examples & $\begin{array}{l}\text { A student is admitted, or a faculty member is hired/promoted, based only on } \\
\text { his/her personal connections and/or family relations; academic achievement } \\
\text { and other relevant competencies are not considered }\end{array}$ \\
\hline $\begin{array}{l}\text { Terms/TI } \\
\text { definitions }\end{array}$ & $\begin{array}{l}\text { Fraud } \\
\text { To cheat: the act of intentionally deceiving someone in order to gain an } \\
\text { unfair or illegal advantage (financial, political, or otherwise) }\end{array}$ \\
\hline Examples & $\begin{array}{l}\text { A student cheats on his/her written assignment, or a faculty member } \\
\text { plagiarizes in his/her paper; } \\
\text { A staff member falsifies an admission application; } \\
\text { A significant amount of a research grant goes to other purposes than what is } \\
\text { indicated in the research proposal; } \\
\text { Universities expect a contribution from students receiving financial support }\end{array}$ \\
\hline $\begin{array}{l}\text { Terms/TI } \\
\text { definitions }\end{array}$ & $\begin{array}{l}\text { Lobbying } \\
\text { Any activity carried out to influence a government or institution's policies } \\
\text { and decisions in favour of a specific cause or outcome }\end{array}$ \\
\hline Examples & $\begin{array}{l}\text { Some industries support research projects expecting positive and/or } \\
\text { promising outcomes for their products/services }\end{array}$ \\
\hline $\begin{array}{l}\text { Terms/TI } \\
\text { definitions }\end{array}$ & $\begin{array}{l}\text { Revolving doors } \\
\text { An individual who moves back and forth between public office and private } \\
\text { companies, exploiting his/her period of government service for the benefit of } \\
\text { the companies he/she used to regulate }\end{array}$ \\
\hline Examples & An influential government official opts for employment as a university rector \\
\hline $\begin{array}{l}\text { Source Updated and expanded version from Denisova-Schmidt 2017a } \\
\text { aThe Anti-Corruption Plain Language Guide. TI. 2009. http://www.transparency.org/whatwedo/ } \\
\text { publication/the_anti_corruption_plain_language_guide }\end{array}$
\end{tabular}

Corruption is typically used as a generic term for a wide range of actions, including favouritism, nepotism, advantage granting, cronyism, and many other activities. Table 1 illustrates some other types of corruption as well as some examples from the higher education sector. All these types might be judged differently depending on the perspective (insiders or outsiders) and the national/cultural context.

\section{Corruption in Bologna Countries}

Virtually all forms of corruption are prevalent in the Bologna countries. According to a 2015 survey conducted in Ukraine, for example, every second student reported an experience with bribery at university (Denisova-Schmidt and Prytula 2017). According to Guardian Data, the number of cheating incidents involving technology (mobile phones, smart watches, etc.) at UK universities increased by $42 \%$ between 2012 and 2016. In 2016 alone, 25\% of students caught cheating used various electronic devices (Marsh 2017). Cheating and plagiarism might happen 
among scholars, too. The Austrian Agency for Research Integrity reported about several recent cases, including double submission of the same proposal or authorship conflict. The latter case was a conflict between a PhD student and her supervisor, which made it impossible for her to defend her dissertation in Austria ("Research Integrity Practices in Science Europe Member Organisations" 2016). In 2016, the Ministers of Education of Armenia, Bosnia and Herzegovina, Croatia, Russia, and Ukraine were all implicated in conflicts of interest. In addition, some or all the deputy Ministers of Education in Armenia, Azerbaijan, Croatia, Moldova, Serbia, and Ukraine, as well as some members of the cabinets in Armenia and Kazakhstan, have also been accused of having conflicts of interest. These ranged from an active for-profit affiliation to an expectation of going through the "revolving door" into a salaried or shareholder position at a university after leaving the public sector. For-profit affiliations with universities were also common among lower-level heads of departments for higher education in Armenia, Azerbaijan, Moldova, Russia, and Serbia, as well as among education-focused legislators in Azerbaijan, Bosnia and Herzegovina, Macedonia, Moldova, Serbia, and Ukraine (Milovanovitch et al. 2018). Milovanovitch et al. (2015) claims that the hiring of faculty members and staff in Armenia is often based on personal relationship rather than on merit; in addition, dismissals of academic staff might occur due to their activism in fighting for their rights or their membership in the political opposition. Dissernet, a community of Russian activities fighting plagiarism in academic writing, including dissertations, created a ranking of university rectors with questionable academic backgrounds who sought to exploit monetary interests in their positions by employing friends and relatives as employees and/or subcontractors. ${ }^{4}$ Some social groups - women, for example — still face several career disadvantages in academia. While there is an increasing trend toward gender balance at the bachelor, master and Ph.D. levels in many countries, the number of female researchers holding top-level positions remains significantly low, for example, in 2013 in Cyprus (10.8\%), the Czech Republic (13.1\%), Lithuania (14.4\%), Belgium (15.6\%), the Netherlands (16.2\%), Luxemburg (16.5\%), Estonia (17.2\%), Germany $(17.3 \%)$, the United Kingdom (17.5\%), Denmark (19.2\%), Switzerland (19.3\%), France $(19.3 \%)$ and Greece (19.6\%) (She Figures 2015). The reasons for this might vary from traditional gender roles in the respective societies to a lack of knowledge of how to develop an academic career more strategically to - in some cases - sexual harassment, including the refusal to provide favours in exchange for career advancement. $^{5}$

\footnotetext{
${ }^{4}$ Rectory: prizvanie i biznes. https://www.youtube.com/watch?v=9xNWeAjSLsY.

${ }^{5}$ It should be mentioned that this topic still remains taboo. The "MeToo" campaign might encourage some victims not to feel alone in their situations and even to act. Recent cases discussed in the media include the court decision against Siegfried Mauser, ex-rector of the Mozarteum University Salzburg and ex-president of the University of Music and Performing Arts Munich, who was found guilty of sexual harassment and rape (Rost 2016; Wimmer 2017).
} 
The geography of the violence of academic integrity is wide; the scope and the techniques might vary, as might the courage of all involved actors to talk about it openly. Some scholars argue that the current situation in many countries leads to "academic collusion" (Titaev 2012), or situations in which almost all of the stakeholders involved in academia might occasionally pretend to teach, carry out research, or study due to high pressure. The following example demonstrates the challenges of this phenomenon.

\section{Favouritism Versus Strong Social Ties}

The situation in which a (new) faculty member is hired and/or promoted based on his/her personal connections and/or family relationships and not on his/her academic achievement or other relevant competencies is called "favouritism"-or corruption, according to TI. Should any personal and/or family relationships be banned per se in university employment decisions? I am familiar with a case that happened at one Russell-Group University in the United Kingdom, where a new faculty member was indeed not hired because his brother had already been working for the same institution. In Germany, on the other hand, according to Kehm, it is almost impossible to get a university professorship without personal networks. This informal "... support is never made public and never openly discussed but will be able to topple ranking lists of candidates established by search commissions" (Kehm 2015, p. 130). The competition is very high: for every five successfully completed habilitations, ${ }^{6}$ there is only one vacant post (Müller 2017). Stipulating the fact that the lack of a formal habilitation might be compensated by a "habilitation equivalency", the situation is even more drastic. More influential people in academia tend to help (young) colleagues for many reasons: one of them might belong to the same research school and/or share similar research ideas and a willingness to continue the work on a particular research topic. But even powerful networks cannot always guarantee a job. A search commission might favour an average candidate over an excellent one in order not to be swayed by the fame of this great researcher when he or she becomes a colleague, or they might decide on a candidate with less informal support in order to spite the personal networks of other competitors (Denisova-Schmidt 2017c). Nevertheless, it is important to have a network and sometimes even belong to the "correct" political party or church. In 2007, for example, Alfred Scharenberg claimed that he was not appointed as a professor of political science at the Free University of Berlin due to his activity in

\footnotetext{
${ }^{6}$ The habilitation is a formal requirement (but not a guarantee) for a full-professorship position at German universities. The search committee might consider candidates who are "habilitation equivalent", however. In some fields such as engineering or economics, a habilitation is not required anymore (cf. Kehm 2015).
} 
the Rosa Luxemburg Foundation (cf. e.g. FU Berlin 2007; Kirchgessner 2007; Wittrock 2007). ${ }^{7}$ Moreover, Ulla Wessels sued the University of ErlangenNuremberg in 2012 for not hiring her as professor of philosophy because she was not Catholic (cf. e.g. Scherf 2012; Auer 2015). While this seems to be an open secret in Germany, the importance of social ties and loyalty in academic life is often stressed explicitly in other countries, as, for example, in Russia (cf. Yudkevich 2015) or the practice of cooptation in France.

\section{Anti-corruption Research and Anti-corruption Measures}

A great deal of contemporary research into corruption assumes that corruption can be defined and quantified clearly, thus allowing it to be combatted successfully (for a contrasting view, see Ledeneva 2009, 2013; Barsukova and Ledeneva 2014; Denisova-Schmidt et al. 2016b; Ledeneva et al. 2017; Denisova-Schmidt and Kryzhko 2018). In such theoretical approaches as the principal-agent (Klitgaard 1988) and rent-seeking models (see Graeff and Grieger 2012), corruption is often defined by researchers as a "deviation from the norm" that can to be eradicated. There are, however, other approaches that examine corruption in its own indigenous context, where it might be considered as a "norm". These approaches are particularly useful in endemically corrupt countries (see, for example, Mungiu-Pippidi 2011; Rothstein 2011), where the fight against corruption is often more difficult since it is deemed to be a collective action (Marquette and Pfeiffer 2015). When people believe that corruption is already widespread, it can even lead to more corruption (John et al. 2014; Corbacho et al. 2016). In Ukraine, a country with a high rate of corruption, two recent experiments have shown that anti-corruption campaigns can actually have the opposite effect: rather than reducing corruption, such campaigns might, in fact, promote it. Examining the effectiveness of anti-corruption measures at state universities in Lviv, Ukraine, a pair of recent studies (Denisova-Schmidt et al. 2015; Denisova-Schmidt et al. 2016a) indicated that young people with previous experience with corruption at university level were not influenced by anti-corruption campaigns based on TI materials, though these students still often judged corruption in negative terms (corruption is "bad" or corruption is a "crime"). For those students who had not encountered corruption at university, however, the studies showed that anti-corruption programs can have the opposite effect: students are able to learn new cheating techniques, and their assumptions about the widespread nature of corruption are confirmed. Marquette and Pfeiffer (2015) argue that anti-corruption measures often fail not because the theories they are based on (i.e., the principal-agent or collective action models) are inadequate (Persson et al. 2013; Mungiu-Pippidi 2011), but rather because such

\footnotetext{
${ }^{7}$ The Rosa Luxemburg Foundation is a German organisation affiliated with the political party The Left.
} 
measures do not allow for the fact that corruption can be a necessary instrument that helps people deal with the problems of everyday life, particularly in an environment of weak institutions. Therefore, those who make policies need to recognize the important role corruption plays and develop equally effective alternatives to replace it. This consideration would boost the efficacy of anti-corruption measures significantly (Denisova-Schmidt and Prytula 2016; Ledeneva et al. 2017).

\section{Remedying Corruption Within the Bologna Process}

In order to combat this corruption, the faculty should present their assignments and expectations more clearly to the students, stipulating their educational and cultural backgrounds. In some cultures, for example, students might have a different concept of the term "plagiarism": some material might be widely considered to be common knowledge and, therefore, does not need to be cited properly. While editing three books $^{8}$ with young Russian authors (undergraduate and graduate students), my colleague and I observed that some of them simply copied and pasted without acknowledging any sources, especially when describing the state of research. One student even argued, "this is only theory". Only after some discussions with those students did we realize the problem: Russian students need to be taught such basic concepts as a precise definition of plagiarism in their academic writing courses. One of the useful arguments here might be mentioning several recent examples of high-profile politicians accused of plagiarism during their university years and the consequences on their professional future. ${ }^{9}$ Additional courses on academic integrity might increase students' awareness significantly (Curtis et al. 2013). Faculty members should serve as role models, however. If they also cheat, they might not be able to demand the opposite behaviour from their students. A large number of (external) proctors for supervising examinations might be an effective remedy, as well as the use of randomized seating and several versions of the same examination (if possible) to prevent copying from a neighbour (Denisova-Schmidt 2017a).

\footnotetext{
${ }^{8}$ Denisova-Schmidt, E. and Leontyeva, E. (2012a), Korrupciia v povsednevnoi zhizni, biznese $i$ kul'ture. Vzgliad rossiiskikh studentov (Corruption in Everyday Life, Business and Culture. A Russian Student Perspective), Europäischer Hochschulverlag, Bremen; Denisova-Schmidt, E. and Leontyeva, E. (2013a), Korrupciia v Rossii: aktual'nye tendencii i perspektivy. Vzgliad rossiiskich studentov (Corruption in Russia: Current Trends and Outlooks. A Russian Student Perspective), Europäischer Hochschulverlag, Bremen; Denisova-Schmidt, E. and Leontyeva, E. (2013c), Siuzhety o korrupcii v rossiiskich fil'mach $i$ serialach: Vzgliad rossiiskich studentov (The Representation of Corruption in Russian Movies and Sitcoms: A Russian Student Perspective), Europäischer Hochschulverlag, Bremen.

${ }^{9}$ Just to name a few examples: German Defense Minister Karl-Theodor zu Guttenberg in 2011, Hungarian President Pal Schmitt in 2012, German Education Minister Annette Schavan in 2013 and Romanian Minister President Victor Ponta in 2016.
} 
In addition to training and raising awareness, creating appropriate policies and procedures on academic integrity might be another very important step for orienting all of the involved stakeholders: students on what is right and what is wrong, as well as faculty members and university administration on what to do in detected cases of academic dishonesty. The University of St. Gallen (Switzerland), for example, defines in its regulations academic dishonesty as follows: "falsifying a candidate's own or another candidate's examination paper, using or making available inadmissible aids or information, failing to comply with general or specific instructions for the conduct of the examination or arrogating other people's intellectual property (plagiarism)" (Examination Regulations 2014). Even attempted dishonesty might be punished. The punishment might include a reduced grade or grading with the lowest possible mark 1.0 (inadequate) or some other sanctions including removal from the university. Sanctions for misconduct and malpractice might be an effective remedy among scholars, as well. The survey report "Research Integrity Practices in Science Europe Member Organisations" (2016), for example, recommended that sanctions be applied for individuals as well as for institutions. Depending on the national context, sanctions against individuals might be covered by (a) employment law, ranging from a written letter of reprimand to dismissal; by (b) civil law, such as financial penalties for copyright infringement or repayments of received funds; and/or by (c) academic policies or professional standards, whereby the tools might include withdrawal of a degree, academic title, or licence, as well as exclusion from membership in an academic society, team, or pool of future grant applicants. Sanctions against institutions are also possible, though uncommon, "because usually it is an individual who has transgressed, not the institution". These sanctions might include repayment of a research grant or a ban on further funding (often for a limited period of time). These issues might be outsourced or they might be regulated by a third agency, as in Austria, for example, with the Austrian Agency for Research Integrity (OeAWI). ${ }^{10}$

Many national governments have implemented programs to promote women in academia, from mentoring to fellowships and vacancies for female researchers only. The Swiss National Science Foundation (SNSF), for example, has offered the Marie Heim-Vögtlin ${ }^{11}$ Program (2001-2016) "for female doctoral students and postdocs in Switzerland who had to interrupt or reduce their research activities due to family commitments". ${ }^{12}$ Since 2017, the SNSF has continued its support for female scholars through the new PRIMA (Promoting Women in Academia) program for

\footnotetext{
${ }^{10} \mathrm{http}: / / w w w . o e a w i . a t / e n / i n d e x . a s p$.

${ }^{11}$ Marie Heim-Vögtlin (1845-1916) was the first female Swiss physician.

${ }^{12}$ See http://www.snf.ch/en/funding/discontinued-funding-schemes/mhv-grants/Pages/default.aspx.
} 
"excellent female researchers from Switzerland and abroad who aspire to a professorship in Switzerland". ${ }^{13}$ Two additional programs for female researchers are named after Lise Meitner (1878-1968), an Austrian-Swedish physicist; these are administered independently by the Austrian Science Fund (FWF) ${ }^{14}$ and the German Max Planck Society, ${ }^{15}$ both with the goal of addressing gender inequality in academia. Several universities have established career paths for women only; in the Netherlands, these include, for example, the University of Groningen, offering Rosalind Franklin Fellowships, or the Delft University of Technology (TU Delft), providing highly qualified women with the Delft Technology Fellowship.

It is crucial to acknowledge this problem and not to treat it as the elephant in the room. General research on corruption suggests not fighting corruption in general but rather focusing on specific malpractices (cf. Shekshnia et al. 2017). The German Academic Exchange Service (DAAD), for example, established the Akademische Prüfstelle (APS) in 2001 in Beijing to prevent Chinese applicants from coming to German universities with fake diplomas. The agency is responsible for validating certificates awarded in China and assessing young people in appropriate discipline. Now German, Austrian, Swiss, and Belgian universities require this document for Chinese applicants. The UK battle against plagiarism might consider this as another ongoing successful example. The Quality Assurance Agency for Higher Education (QAA) recently published a report on the "growing threat to UK higher education from custom essay writing services" or "essay mills". The agency develops concrete actions to be taken against companies providing such services. Inspired by the experience of New Zealand, which has fined and even frozen the assets of essay mills, QAA suggests the introduction of the same procedure. Milovanovich et al. (2015) in their study on academic integrity in Armenia suggest first to look at a single case of suspected integrity violation, then describe and determine the factors that create incentives for the integrity violation and, based on this analysis, develop pointers for action. The researchers name two main reasons for the widespread cheating among Armenian students: "the lack of intrinsic motivation to study" and "overloaded and/or outdated study content" and argue that, by addressing these two issues, cheating might decrease.

Some measures might be easily implemented, so why have not all universities within the Bologna process done it? Why do not all universities clear procedures and policies on the ethical behaviour? Why do not all universities use anti-plagiarism software programs and take legal actions against companies providing questionable services? Some of the measures might be costly. Take for example the use of anti-plagiarism software in Ukraine: a company offering such

\footnotetext{
${ }^{13}$ See http://www.snf.ch/en/funding/careers/prima/Pages/default.aspx.

${ }^{14}$ For more about the "Lise Meitner Programme", see https://www.fwf.ac.at/en/research-funding/ fwf-programmes/meitner-programme/.

${ }^{15}$ For more about "The Lise-Meitner excellence programme", see https://www.mpg.de/11767653/ lise-meitner-programme.
} 
services currently charges 1 hryvnia per page ${ }^{16}$; therefore, many universities can only afford to check bachelor/master/Ph.D. theses (if at all) and not term papers. Some measures mean more additional resources and/or obligations for already overworked faculty members and university administrations. Some measures might not be implemented yet due to weak management, while other measures might be not implemented concisely. Corruption seems to be a very effective tool to respond to massification, falling or insecure financial support, and growing competition among institutions on the national and international levels, as well as to the increasing demands on university researchers and instructors. Tackling these issues might be a good and effective strategy for tackling corruption.

The negative consequences of corruption in higher education are particularly severe: in their last formative years, students consciously and/or unconsciously learn that corruption is widespread and even "normal"-behaviour that these young people might transfer to their future professional lives (Heyneman 2013; Denisova-Schmidt 2013, 2016a, b, c). No one should ever wonder if graduates in medicine would become involved in promoting drugs without evidence, if managers would cheat and steal, or if lawyers and bankers would develop new schemes for tax evasion and fraud. Universities should incorporate ethical issues into their curricula and certainly act ethically and transparently themselves, as was suggested in the Poznan Declaration- "a formal statement aimed at mainstreaming ethics and anti-corruption in higher education" endorsed by 68 member universities of Compostela Group of Universities, the World University Consortium, the World Academy of Art and Science and TI. The decision-makers within the Bologna process should support and encourage exchanges on this topic among all involved stakeholders on practical issues, as well as more reflection and research on blind spots and borders between legal and illegal, good and bad, acceptable and unacceptable practices.

\section{Conclusion}

What can educators and decision-makers within the Bologna process learn from general corruption research? First of all, many anti-corruption reforms failed not because they were based on inefficient theories, or because the involved stakeholders lacked the courage to implement the new reforms, but because the decision-makers did not consider the functions that corruption might serve, especially in weak institutional environments. In higher education, corruption might often be considered an effective tool to address the challenges of massification, internationalisation and shrinking financing. Hence the latter issues should be considered when developing anti-corruption strategies and measures within the higher education sector. Secondly, such measures should not attempt to address

\footnotetext{
${ }^{16}$ The current average monthly salary in Ukraine is 750 hryvnias (about 275 USD).
} 
corruption in general, but rather focus on specific practices, such as the recent initiatives of the UK government to hinder the operations of essay mills within the country or the "old" practice developed by the German Akademische Prüfstelle (APS) of checking the creditability of Chinese students applying to study in the German-speaking countries. Such remedies might have a controlling function, as in the case of anti-plagiarism software programs, or a preventing function, as in training on academic integrity. Last, but not least, it is crucial to start addressing this phenomenon using all the available resources within the Bologna process, to admit its existence and scope and to work together to mitigate it.

\section{References}

Auer, K. (2015). Verfassungsklage abgewiesen: Süddeutsche Zeitung, 3 November 2015. Retrieved from http://www.sueddeutsche.de/bayern/uni-erlangen-verfassungsklage-abgewiesen-1.2720144.

Barsukova, S., \& Ledeneva, A. (2014). Ot global'noi korruptsionnoi paradigmy k izucheniyu neformal'nykh praktik: razlichiya $\mathrm{v}$ podkhodakh autsaiderov i insaiderov [From Global Corruption Paradigm to the Study of Informal Practices: Outsiders vs. Insiders]. Voprosy Ekonomiki, 2, 118-132.

Chapman, D. W., \& Lindner, S. (2016). Degrees of integrity: The threat of corruption in higher education. Higher Education, 41(2), 247-268.

Corbacho, A., Gingerich, D. W., Oliveros, V., \& Ruiz-Vega, M. (2016). Corruption as a self-fulfilling prophecy: Evidence from a survey experiment in Costa Rica. American Journal of Political Science, 60(4), 1077-1092.

Curtis, G., \& Vardanega, L. (2016). Is plagiarism changing over time? A 10-year time-lag study with three points of measurement. Higher Education Research \& Development. Higher Education Research \& Development on January 21, 2017.

Curtis, G. J., Gouldthorp, B., Thomas, E. F., O'Brien, G. M., \& Correia, H. M. (2013). Online academic-integrity mastery training may improve students' awareness of, and attitudes toward, plagiarism. Psychology: Learning and Teaching, 12(3), 282-289.

Denisova-Schmidt, E. (2013). Justification of academic corruption at Russian universities: A student perspective. In E. J. Safra (Ed.), Working Papers (p. 30). Cambridge, MA: Harvard University. Retrieved 24 March 2017, from doi: http://dx.doi.org/10.2139/ssrn.2353513.

Denisova-Schmidt, E. (2016a). Corruption in Russian higher education. Russian Analytical Digest, 191(5-9).

Denisova-Schmidt, E. (2016b). Academic dishonesty or corrupt values: The case of Russia. In D. Torsello (Ed.), Corruption in public administration: An ethnographic approach (pp. 105-137). Edward Elgar.

Denisova-Schmidt, E. (2016c). The global challenge of academic integrity. International Higher Education, 87(4-6). Retrieved 24 March 2017, from http://ejournals.bc.edu/ojs/index.php/ihe/ article/view/9494.

Denisova-Schmidt, E. (2017a). The challenges of academic integrity in higher education: Current trends and outlook. In CIHE Perspectives (Vol. 5). Boston: Boston College.

Denisova-Schmidt, E. (2017b). Corruption in higher education. In J. C. Shin, \& P. Teixeira (Eds.), Encyclopedia of international higher education systems and institutions. Springer.

Denisova-Schmidt, E. (2017c). The challenges of an academic career for women in Switzerland. Higher Education in Russia and Beyond (HERB) Fall, 14(4), 16-17. 
Denisova-Schmidt, E. (2018a). Shpargalka. In A. Ledeneva (Ed.), The global encyclopaedia of informality (Vol. 2, pp. 287-289). Understanding social and cultural complexity. London: UCL Press.

Denisova-Schmidt, E. (2018b). Corruption, BRIC universities and the effect on global higher education: Causes, techniques and remedies. Basingstoke. New York: Palgrave Macmillan, forthcoming in 2018.

Denisova-Schmidt, E., \& de Wit, H. (2017). The global challenge of corruption in higher education. IAU Horizons, 22(1), 28-29.

Denisova-Schmidt, E., \& Prytula, Y. (2016). Perceived corruption and trust among Ukrainian firms. Eastern European Economics, 55, 324-341.

Denisova-Schmidt, E., \& Prytula, Y. (2017). Ukraine: Endemic higher education corruption. International Higher Education, 90, 16-18. Retrieved from https://ejournals.bc.edu/ojs/index. php/ihe/article/view/10000.

Denisova-Schmidt, E., Huber, M., \& Prytula, Y. (2015). An experimental evaluation of an anti-corruption intervention among Ukrainian university students. Eurasian Geography and Economics, 56(6), 713-734.

Denisova-Schmidt, E., Huber, M., \& Leontyeva, E. (2016a). Do anti-corruption educational campaigns reach students? Some evidence from two cities in Russia and Ukraine. Voprosy Obrazovaniia. Retrieved from https://vo.hse.ru/2016-1/178805268.html.

Denisova-Schmidt, E., Huber, M., \& Prytula, Y. (2016b). Corruption among Ukrainian businesses: Do firm size, industry and region matter? In J. Leitner, \& H. Meissner (Eds.), State capture, political risks and international business. Cases from the black sea region (pp. 108-119). London and New York: Routledge.

Denisova-Schmidt, E., \& Kryzhko, O. (2018). Weiterbildung zum Umgangmit Korruption in Russland. In S. Wolf, \& P. Graeff (Eds.), Korruptionsbekämpfung vermitteln (pp. 269-288). Springer VS: Wiesbaden.

Examination Regulations for the Bachelor's Level of the University of St. Gallen. (2014). University of St. Gallen: St. Gallen.

FU Berlin. (2007). Der Fall Scharenberg. Tagesspiegel. 16.10.2007 http://www.tagesspiegel.de/ wissen/fu-berlin-der-fall-scharenberg/1069356.html.

Golunov, S. (2014). The elephant in the room. Corruption and cheating in Russian universities. Stuttgart: Ibidem Verlag.

Graeff, R., \& Grieger, J. (2012). Was ist Korruption?. Baden-Baden: Nomos.

Heyneman, S. P. (2013). Higher education institutions: Why they matter and why corruption puts them at risk. In G. Sweeney, K. Despota, \& S. Lindner (Eds.), Global corruption report: Education, transparency international. Earthscan by Routledge: Abingdon.

John, L., Loewenstein, G., \& Rick, S. (2014). Cheating more for less: Upward social comparisons motivate the poorly compensated to cheat. Organizational Behavior and Human Decision Processes, 123, 101-109.

Kehm, B. M. (2015). Entering academia: Realities for new faculty in german higher education. In M. Yudkevich, P. Altbach, \& L. Rumbley (Eds.), Young faculty in the twenty-first century. International perspectives (pp. 111-140). Suny Press.

Kirchgessner, K. (2007, November 11). Hartnäckiges Schweigen. Der FU-Präsident blockiert die einfache Berufung eines Juniorprofessors. Warum? Retrieved from http://www.zeit.de/2007/ 45/C-FU-Berufungsverfahren.

Klitgaard, R. (1988). Controlling corruption. Berkeley: University of California Press.

Ledeneva, A. (2009). Corruption in postcommunist societies in Europe: A re-examination. Perspectives on European Politics and Society, 10(1), 69-86.

Ledeneva, A. (2013). A critique of the global corruption "paradigm". In J. Kubik, \& A. Linch (Eds.), Postcommunism from within: Social justice, mobilization, and hegemony (Vol. 296332). New York: NYU Press. 
Ledeneva, A., Bratu, R., \& Köker, P. (2017). Corruption studies for the twenty-first century: Paradigm shifts and innovative approaches. Slavonic and East European Review, 95(1), 1-20.

Marquette, H., \& Pfeiffer, C. (2015). Corruption and collective action. Research Paper (p. 32). Chr. Michelsen Institute (CMI): Bergen.

Marsh, S. (2017, April 10). More university students are using tech to cheat in exams. The Guardian. Retrieved from https://www.theguardian.com/education/2017/apr/10/moreuniversity-students-are-using-tech-to-in-exams.

Milovanovitch, M., Ceneric, I., Avetisyan, M., \& Khavanska, T. (2015). Strengthening integrity and fighting corruption in education in Armenia. Yerevan. Retrieved from www.osf.am/wpcontent/uploads/2016/01/Integrity-report_final_en_12.11.2015.pdf.

Milovanovitch, M., Denisova-Schmidt, E., \& Anapiosyan, A. (2018). Conflict of interest in Eastern Europe: “Academic capture”. International Higher Education, Winter, 2018, 29-30. https://ejournals.bc.edu/ojs/index.php/ihe/article/view/10289.

Müller, M. (Ed.). (2017). DIE ZEIT CHANCEN Brief: "Dr. acad. Sommer" zur Frage "Für die Karriere in der Wissenschaft reicht's vermutlich nicht, und in der freien Wirtschaft habe ich mich bisher erfolglos beworben. Vermutlich bin ich zu alt und ohne praktische Erfahrung. Mein Forschungsprojekt läuft in einem Jahr aus. Und dann?" DIE ZEIT CHANCEN Brief vom 27. Juli 2017 Retrieved from http://www.coachingnetz-wissenschaft.de/wp-content/uploads/ 2017/07/M\%C3\%BCller20170727.pdf.

Mungiu-Pippidi, A. (Ed.) (2011). Contextual choices in fighting corruption: Lessons learned. NORAD Report 4/2011. Retrieved from www.norad.no/en/tools-and-publications/ publications/publication?key $=383808$.

Persson, A., Rothstein, B., \& Teorell, J. (2013). Why anticorruption reforms fail systemic corruption as a collective action problem. Governance, 26(3), 449-471.

Rost, C. (2016). Mit Verlaub, Sie sind ein Grapscher, Süddeutsche Zeitung, 13. Mai, 2016. Retrieved from http://www.sueddeutsche.de/muenchen/amtsgericht-mit-verlaub-sie-sind-eingrapscher-1.2993297.

Rothstein, B. (2011). Anti-corruption: The indirect 'big bang' approach. Review of International Political Economy, 18(2).

She Figures. (2015). Gender in research and innovation. Luxembourg: Publications Office of the European Union. Retrieved from https://data.europa.eu/euodp/data/dataset/she-figures-2015gender-in-research-and-innovation.

Scherf, M. (2012). Wie die katholische Kirche eine Professorin verhinderte. Süddeutsche Zeitung, 18. April 2012. Retrieved from http://www.sueddeutsche.de/bayern/philosophin-reichtverfassungsklage-ein-wie-die-katholische-kirche-eine-professorin-verhinderte-1.1335177.

Shekshnia, S., Ledeneva, A., \& Elena, D.-S. (2017). Managing business corruption: Targeting non-compliant practices in systemically corrupt environments. Slavonic \& East European Review, 95(1), 151-174.

Titaev, K. D. (2012). Akademicheskii sgovor. Otchego rossiiskie vuzy stanoviatsia "zaborostroitel'nymi institutami" [Academic collusion. Why Russian universities are becoming "fence-building institutions"]. Otechestvennye Zapiski., 47(2). Retrieved from http://www. strana-oz.ru/2012/2/akademicheskiy-sgovor.

Wimmer, S. (2017). Dann hat er sich an mir zu schaffen gemacht. Süddeutsche Zeitung, 27. November 2017 http://www.sueddeutsche.de/muenchen/prozess-dann-hat-er-sich-an-mir-zuschaffen-gemacht-1.3768160.

Wittrock, P. (Ed.) (2007). Linke Nummer an der FU Berlin. Spiegel Online. Retrieved from https:// www.uni-freiburg.de/universitaet/einzelgutachten/Gutachten-Armin-Kluemper.pdf.

Yudkevich, M. (2015). The university sector in Russia. Young romantics and losers welcome? In M. Yudkevich, P. Altbach, \& L. Rumbley (Eds.), Young faculty in the twenty-first century. International perspectives (pp. 227-252). Suny Press. 
Open Access This chapter is licensed under the terms of the Creative Commons Attribution 4.0 International License (http://creativecommons.org/licenses/by/4.0/), which permits use, sharing, adaptation, distribution and reproduction in any medium or format, as long as you give appropriate credit to the original author(s) and the source, provide a link to the Creative Commons license and indicate if changes were made.

The images or other third party material in this chapter are included in the chapter's Creative Commons license, unless indicated otherwise in a credit line to the material. If material is not included in the chapter's Creative Commons license and your intended use is not permitted by statutory regulation or exceeds the permitted use, you will need to obtain permission directly from the copyright holder.

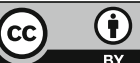

